\title{
Determinants of seasonal changes in availability of food patches for elephants (Loxodonta africana) in a semi-arid African Savanna
}

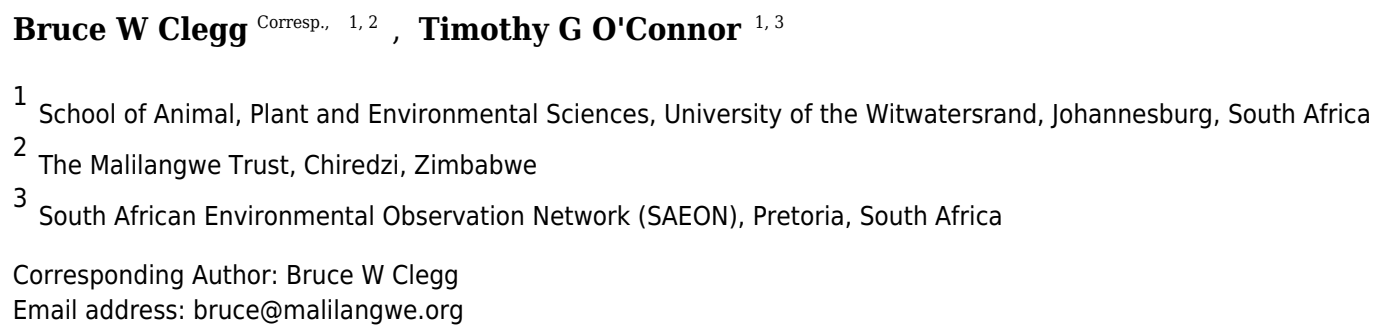

Loss of biodiversity caused by impact of elephants (Loxodonta africana) on African woodlands may require a management response, but any action should be based on an understanding of why elephants choose to utilise trees destructively. Comprehension of elephant feeding behaviour requires consideration of the relative value of the plant groups they may potentially consume. Profitability of available food is partly determined by the time to locate a food patch and, therefore, as a foundation for understanding the influence of food availability on diet selection, key controls on the density of grass, forb, and browse patches were investigated across space and time in a semi-arid African savanna. Density of food patches changed seasonally because plant life-forms required different volumes of soil water to produce green forage; and woody plants and forbs responded to long-term changes in soil moisture, while grasses responded to short-term moisture pulses. Soil texture, structure of woody vegetation and fire added further complexity by altering the soil water thresholds required for production of green forage. Interpolating between regularly-timed, ground-based measurements of food density by using modelled soil water as the predictor in regression equations may be a feasible method of quantifying food available to elephants in complex savanna environments. 
1 Determinants of seasonal changes in availability of food patches for elephants (Loxodonta

2 africana) in a semi-arid African Savanna

3

4 Bruce W. Clegg 1,2,*, Timothy G. O’Connor ${ }^{1,3}$

5

$6 \quad{ }^{1}$ School of A.P.E.S., University of the Witwatersrand, Johannesburg, South Africa

$7 \quad 2$ The Malilangwe Trust, Chiredzi, Zimbabwe

$8 \quad{ }^{3}$ South African Earth Observation Network, Pretoria, South Africa

9

10 *Corresponding author: Bruce Clegg bruce@malilangwe.org

11

12

13

14

15

16

17

18

19

20

21

22 


\section{ABSTRACT}

24 Loss of biodiversity caused by impact of elephants (Loxodonta africana) on African woodlands

25 may require a management response, but any action should be based on an understanding of why

26 elephants choose to utilise trees destructively. Comprehension of elephant feeding behaviour

27 requires consideration of the relative value of the plant groups they may potentially consume.

28 Profitability of available food is partly determined by the time to locate a food patch and,

29 therefore, as a foundation for understanding the influence of food availability on diet selection,

30 key controls on the density of grass, forb, and browse patches were investigated across space and

31 time in a semi-arid African savanna. Density of food patches changed seasonally because plant

32 life-forms required different volumes of soil water to produce green forage; and woody plants

33 and forbs responded to long-term changes in soil moisture, while grasses responded to short-term

34 moisture pulses. Soil texture, structure of woody vegetation and fire added further complexity by

35 altering the soil water thresholds required for production of green forage. Interpolating between

36 regularly-timed, ground-based measurements of food density by using modelled soil water as the

37 predictor in regression equations may be a feasible method of quantifying food available to

38 elephants in complex savanna environments. 


\section{INTRODUCTION}

45 African savannas are characterised by a predominance of woody plants and grasses (Huntley

46 1982), but they also support a richness of herbaceous dicotyledons (forbs). Savanna elephants

47 (Loxodonta africana) harvest food from all these plant types (Barnes 1982; Field 1971;

48 Kabigumila 1993), but their conspicuous impact on woody plants has the greatest potential to

49 cause long-term vegetation change (Lamprey et al. 1967; Laws 1970b; Leuthold 1977). Over

50 time, this behaviour may simplify the structure and composition of woodlands ( $\mathrm{O}^{\prime}$ Connor \&

51 Page 2014), jeopardising the persistence of impacted species (Lombard et al. 2001; O'Connor et

52 al. 2007) and the biota that are dependent on the original complexity (Cumming et al. 1997;

53 Herremans 1995; Kerley \& Landman 2006). Extensive impact on woodlands by elephants was

54 first noticed in the 1930s (Laws 1970a) and since then many wooded areas in Africa have been

55 converted to shrubland or grassland (Spinage 1994). The threat of local extirpation of some

56 impacted woody species (O'Connor et al. 2007) begs a management response, but any action

57 should be founded upon an understanding of why elephants choose to use woody plants in a

58 destructive manner.

Comprehension of elephant feeding patterns requires consideration of the relative value

60 of the plant groups they may potentially consume. Savanna elephants may utilise grasses,

61 including roots (de Boer et al. 2000; de Longh et al. 2004; Wyatt \& Eltringham 1974), forbs

62 (Barnes 1982; Field 1971), and all components of woody plants (Field 1971; Guy 1976). They

63 adjust their diet seasonally depending on food availability (Cerling et al. 2004; Owen-Smith

64 1988). During the wet summer months large amounts of grass and forbs are eaten, but when

65 these food types dry out in winter, elephants consume an increasing amount of leaves and twigs

66 from woody plants, followed by bark and roots as leaves are shed. 
breaking branches, debarking stems, or toppling, pollarding or uprooting whole plants, and less when trunkloads of leaves are stripped without breaking branches (Clegg 2010). When diet is composed solely of grass and forbs there is no damage to woody plants. Prediction of diet is therefore a crucial step towards forecasting impact on woody vegetation. when deciding where to forage and what to eat (Senft et al. 1987), which necessitates a landscape-level assessment of the relative availability of forage types. Elephants may forage for 18 hours a day to meet their needs (Wyatt \& Eltringham 1974), thus searching time for food patches is critical. Patch density of a forage type therefore provides a functional measure of food availability because the distance between patches determines the searching time to locate food, which is a constraint to intake (Fortin et al. 2015). Food availability therefore differs among vegetation types in relation to differences in food-patch densities. Food availability also varies seasonally over an annual cycle. Accordingly, environmental influences on the leaf phenology of forage types were examined.

83 for leaf flush and drop of woody plants, for which levels of internally stored water (Borchert

84 1994; Chapotin et al. 2006; Kulmatiski et al. 2010), photoperiod and temperature play an 85 important role (Archibald \& Scholes 2007; Choler et al. 2010). However, evidence for an 86 influence of soil water on the phenology of woody plants includes early leaf drop in response to 87 low rainfall in the preceding wet season (Borchert et al. 2002), woody plants that receive early 88 rain flush first (Borchert et al. 2002; Clegg 2010), and that internally stored water has to be 
89 recharged from the soil store. Environmental influences on the growth of forbs in African

90 savannas are unstudied.

91 The amount of soil water that is available for uptake by plants is a function of rainfall

92 pattern, soil storage capacity as influenced by profile depth and soil texture, and evapo-

93 transpirative demand (Ritchie 1981). Clay-rich soils store more water at field capacity than sandy

94 soils but this is partly offset by clay soils holding a greater proportion of water more tightly

95 within the pores (Foth 1990). A tendency for higher water-use efficiency (WUE) of tropical $\mathrm{C}_{4}$

96 grasses relative to tropical $\mathrm{C}_{3}$ forbs and woody plants (Ehleringer \& Monson 1993) may lead to

97 differences in leaf phenology between these plant groups. Inter-plant competition for soil

98 moisture influences the duration of leaf carriage in savanna (Smit 2001).

99 Available nutrients and fire also influence food availability. The influence of soil

100 nutrients corresponds directly with that of soil texture (Foth 1990), an effect that cannot be

101 isolated from the influence of soil texture on soil water availability. That fire has an immediate

102 effect on food availability is obvious, but subsequent effects on plant phenology and available

103 forage are poorly understood.

The aim of this study was to investigate key determinants of food available to elephants across space (vegetation types) and time (annual cycle) as a foundation for understanding forage selection. The following specific questions were addressed. (1) Can plant-available water in the soil be used to predict the availability of the main food types? (2) Do different food types differ in their annual pattern of availability? (3) Is the relation between food availability and soil water influenced by soil texture? (4) Does soil texture influence the effect of fire on food availability?

110 (5) Does the structure of woody vegetation influence the annual phenological pattern? 
111 The study formed the foundation of a landscape scale analysis of elephant foraging

112 behaviour that will be reported elsewhere. The findings are relevant to savanna elephants

113 throughout Africa, and are also applicable to other herbivores that inhabit savannas globally. The

114 results concerning the relationship between soil water and the leaf phenology of the plant

115 growth-forms are novel and, although particular emphasis was given to foraging elephants, the

116 findings also make a contribution to the general theory of savanna function.

118 MATERIALS \& METHODS

119 The study was conducted in the semi-arid savanna of Malilangwe Wildlife Reserve in south120 eastern Zimbabwe $\left(20^{\circ} 58^{\prime}-21^{\circ} 15^{\prime} \mathrm{S}, 31^{\circ} 47^{\prime}-32^{\circ} 01^{\prime} \mathrm{E}\right)$. The reserve has a hot wet season from

121 November to March, a cool dry season from March to August, and a hot dry season from

122 September to October. Mean annual rainfall is $557 \mathrm{~mm}(\mathrm{n}=64 ; \mathrm{CV}=34.2 \%)$, with

123 approximately $84 \%$ falling in the hot wet season. Rainfall during the year under study was 716

$124 \mathrm{~mm}$. The average minimum and maximum monthly temperatures range from $13.4{ }^{\circ} \mathrm{C}$ (July) to

$12523.7^{\circ} \mathrm{C}$ (December), and $23.2^{\circ} \mathrm{C}$ (June) to $33.9^{\circ} \mathrm{C}$ (November) respectively (Clegg 2010). Frost

126 is rare. Thirty-eight vegetation types, from open grassland to dry deciduous forest, have been

127 identified on seven geological types, with soils ranging from $90 \%$ sand to $41 \%$ clay (Clegg \&

128 O'Connor 2012). Fire has been used as a tool for rangeland management since 1994.

129 Management burns were conducted in October 2001, 5 months prior to the start of the study

130 period. Permission to conduct the study was granted by the Director of The Malilangwe Trust.

131 The study focused on grass, forbs, and leaves and bark from woody plants because these

132 constitute the bulk of an elephant's diet (Barnes 1982; de Boer et al. 2000; Field 1971; Guy

133 1976). Maps of the areas burnt during the previous year and areas that experienced early woody 
134 leaf flush (identified from an October 2002 landsat 7 ETM+ image using a Normalized

135 Vegetation Index) were combined with a fine-scale vegetation map (Clegg \& O'Connor 2012) to

136 create a spatial framework for sampling with 65 landscape units. Within each unit, the

137 relationship between the density of grass, forb, or leaf patches and soil water was investigated

138 between March 2002 and March 2003. The density of bark patches, whose availability was

139 considered constant for a year, was estimated for each landscape unit. Sampling was undertaken

140 between November 2001 and July 2003 at approximately three-month intervals. On each

141 occasion, five sample points were positioned in each landscape unit using a stratified random

142 strategy and located in the field using a GPS. Plant nomenclature follows Mapaura and

143 Timberlake (2004).

\section{Estimation of the density of food patches}

\section{Grass and forbs}

147 An individual grass tuft or forb plant would constitute a patch if it was growing in isolation, but 148 at high plant densities a trunkload would be made up of material from multiple plants. A $1 \mathrm{~m}^{2}$ 149 area was therefore arbitrarily defined as the patch size for grasses and forbs.

150 The nutritional quality of savanna grasses varies over the annual cycle (Buxton \&

151 Redfearn 1997; Lyons et al. 1996). Elephants avoid eating senescent forage, so a plant can only

152 be considered a patch if it offers a sufficient ratio of green to dry material (Clegg 2010; Loarie et

153 al. 2009). Accordingly, the density of patches with green grass only, or a mixture of green and

154 dry grass were estimated. In support of recognising two grass patch types, elephants require

155 twice the time to harvest, clean by shaking, chew and ingest a trunkload of mixed grass than one 
156 of green grass (Clegg \& O’Connor 2016). When most forbs senesce their leaves are abscised and

157 their stems wither, therefore only the density of patches with green forbs was estimated.

158 At each sampling point, $251 \mathrm{~m}^{2}$ quadrats were sampled along a $50 \mathrm{~m}$ tape. The cover of

159 green grass, dry grass and green forbs was estimated in each quadrat using an eight point scale $(0$

$160 \% ; 1 \% ; 2-10 \% ; 11-25 \% ; 26-50 \% ; 51-75 \% ; 76-95 \% ; 96-100 \%)$. A quadrat was assigned to a

161 patch type using the following criteria: green grass = green grass cover $\geq 1 \%, \geq 90 \%$ of total

162 grass biomass green, and total grass cover $\geq 1 \%$; mixed green and dry grass $\leq 90 \%$ and $\geq 10 \%$

163 of total grass biomass green; green forb $=$ green forb cover $\geq 2 \%$. The density of patches $\left(\mathrm{m}^{-2}\right)$

164 with green grass, mixed green and dry grass, and green forbs was calculated per site.

\section{Leaves from woody plants}

167 Individual shrubs and trees were considered patches. Elephants avoid eating senescent leaves

168 (Clegg 2010) and for this reason only woody plants with $>25 \%$ of their canopies with green leaf

169 were used to estimate patch density. Below this level it becomes difficult for elephants to harvest

170 a trunkload that is comprised solely of green leaves (Clegg 2010). Elephants also avoid very

171 young, red leaves of Colophospermum mopane possibly because of a high concentration of

172 polyphenols and resins (Styles \& Skinner 1997), and therefore mopane plants with this leaf type

173 were excluded. Other species that were also excluded because they were avoided by elephants

174 were Courbonia glauca, Euclea divinorum, Salvadora persica, and Thilachium africanum.

175 The density of woody plants with green leaf was estimated in the following way. At each

176 site the nearest woody plant was assessed and the following recorded: (1) species, (2) shrub $(\leq 3$

$177 \mathrm{~m})$ or tree $(>3 \mathrm{~m}),(3)$ per cent of canopy volume with new leaves, and (4) per cent of canopy 
178 volume with mature green leaves, using the eight-point scale. Then the next nearest individual

179 was assessed in the same way. This process was repeated until five trees and five shrubs of each

180 species had been sampled. To reduce sampling, only species with a canopy volume $>25$ and $>$

$18115 \mathrm{~m}^{3} \mathrm{ha}^{-1}$ were sampled for trees and shrubs respectively (calculation of volume given in Clegg

$182 \&$ O'Connor (2012)). For each species of tree and shrub, an average $(n=25)$ estimate was

183 derived for each date. To improve the temporal resolution for each shrub and tree species, data

184 were pooled across landscape units with similar topo-edaphic conditions. The per cent canopy

185 volume with new green leaf $\left(V_{\text {new }}\right)$ and mature green leaf ( $\left.V_{\text {mature }}\right)$ was estimated, on a daily basis,

186 for each species of shrub and tree in a landscape unit by interpolating between data points using

187 a smoothing spline regression (KyensLab 2002). The total per cent canopy volume with green

188 leaf was calculated, for each shrub and tree species in a landscape unit, as:

$$
V_{\text {total }}=V_{\text {new }}+V_{\text {mature }}
$$

Bull elephants are taller than cows and are therefore capable of stripping leaves from a

191 greater height. It was determined from field measurements that bulls and cows $(\mathrm{n}=200$ each)

192 can feed from a maximum height of just over 6 and $4 \mathrm{~m}$, respectively (see Clegg 2010 for

193 details). The density of woody plants with green leaf available to bulls $\left(D_{\text {bull }}\right)$ was calculated on a

194 daily basis, for each vegetation unit, as:

$$
D_{\text {bull }}=\sum_{i=1}^{n} d_{i, \text { tree }, \text { bull }} p_{i, \text { tree }}+\sum_{i=1}^{n} d_{i, \text { shrub }} p_{i, \text { shrub }}
$$

where $d_{i, \text { tree, bull }}$ is the density of the $i^{\text {th }}$ tree species with canopy volume below $6 \mathrm{~m}$ (see (2012) for

197 how density of each species was calculated), $p_{i, \text { tree }}$ is the Boolean probability ( 0 or 1$)$ that

$198 V_{\text {total,i,tree }}>25 \%, d_{i, \text { shrub }}$ is the density of the $i^{\text {th }}$ shrub species and $p_{i, s h r u b}$ is the Boolean probability 
199 ( 0 or 1 ) that $V_{\text {total,i,shrub }}>25 \%$. The calculation was the same for cows except $d_{i, \text { tree,cow }}$ was based 200 on trees and shrubs with canopy volume below $4 \mathrm{~m}$.

202 Bark

203 Individual shrubs and trees of species whose branches were commonly chewed for bark were 204 considered patches. The density of patches with bark available to bulls, in each landscape unit, 205 was calculated as:

206

$$
D_{\text {bull }}=\sum_{i=1}^{n} d_{i, s h r u b}+\sum_{i=1}^{n} d_{i, \text { tree }, \text { bull }}
$$

207 where $d_{i, \text { shrub }}$ is the density of the $i^{\text {th }}$ shrub species utilised for bark and $d_{i, \text { tree, bull }}$ is the density of 208 the $i^{\text {th }}$ tree species that was utilised for bark with canopy below $6 \mathrm{~m}$. The calculation was the 209 same for cows except $d_{i, \text { tree }}$ was based on the density of trees with canopy below $4 \mathrm{~m}$.

\section{Estimation of soil water}

212 A simple model of soil water that estimated water in the upper soil layer and ignored the process 213 of deep drainage was considered adequate. Daily moisture in the top $30 \mathrm{~cm}$ of soil was extracted

214 for each sample site from maps generated by linking a model of soil moisture balance (Hobbs et

215 al. 1994) to a geographic information system. A constant profile depth of $30 \mathrm{~cm}$ was used

216 because $50 \%$ of the study area had soil $\leq 30 \mathrm{~cm}$ deep (Clegg \& O'Connor 2012) and in savannas

217 most active roots of woody and herbaceous plants occur within this depth (Kulmatiski et al.

218 2010). Daily moisture loss from the $0-30 \mathrm{~cm}$ profile was modelled using a negative exponential 
219 function that was dependent on available soil moisture and driven by daily rainfall and potential 220 evaporation:

$$
M_{t}=\left(M_{t-1}+R_{t}\right) \times \exp ^{-k \cdot P E}
$$

222

223

225

226

227

228

229

230

231

232

234

235

236

237

238

where $M$ is the soil moisture fraction, $R$ is the rainfall fraction, $P E$ is potential evaporation (mm) and $k$ is an evaporative constant. $M$ was scaled between 0 and 1 , and was calculated as:

$$
M=\frac{m_{\text {soil }}-m_{\min }}{m_{F C}-m_{\min }}
$$

where $m_{\text {soil }}$ is the moisture $(\mathrm{mm})$ in the $0-30 \mathrm{~cm}$ profile, $m_{\min }$ is the minimum air dried moisture $(\mathrm{mm})$, and $m_{F C}$ is the field capacity of the $0-30 \mathrm{~cm}$ profile. If the soil profile was less than 30 $\mathrm{cm}, m_{F C}$ was calculated for the actual soil depth. Minimum air dried moisture was calculated for each vegetation unit from per cent silt and clay (Clegg \& O'Connor 2012) using the equation of Bennie et al. (1988). Field capacity was calculated using the equation of Hutson (1984). $R$ was scaled between 0 and 1 and was calculated by dividing daily rainfall (mm) by $m_{F C}-m_{\min }$.

Rainfall data were collected from 14 gauges within and 12 gauges outside the study area. A rainfall surface was generated for each rainfall event by interpolating between gauges using a triangular irregular network (Eastman 2003). Following Hobbs et al. (1994) the evaporative constant $k$ was derived from $m_{m i n}$. Daily $P E$ data were collected from two class A evaporation pans that were located at the Zimbabwe Sugar Association, $27 \mathrm{~km}$ to the west of Malilangwe headquarters.

\section{Relationship between density of food patches and soil water}




\section{Curve fitting}

240 For each landscape unit, the average density of food patches $(D)$ on a particular date was plotted

241 against average soil moisture for the previous $5,10,15,20,25,30,45,60,75,90,105,120,135$

242 and 150 days. The relationship for green grass and forbs could be described by a monotonically

243 increasing sigmoidal curve, with lower and upper asymptotes 0 and 1 respectively (Fig 1). Green

244 leaves from woody plants showed a similar relationship, but the data for each land unit required

245 standardisation to achieve asymptotes of 0 and 1 . Consequently, for these forage types the

246 logistic equation:

$$
D=\frac{1}{1+\exp ^{a-b M}}
$$

248

249

250

251

252

The relationship between the density of mixed grass patches and soil moisture was initially a monotonically increasing sigmoidal curve that was followed at higher levels of soil moisture by a monotonically decreasing sigmoidal curve (Fig 1). Consequently, the following model was fitted to the data for density of mixed grass patches:

$$
D=\left(\frac{1}{1+\exp ^{a-b M}}\right) \times\left(\frac{1}{1+\exp ^{c-d M}}\right)
$$

where $a, b, c$ and $d$ are constants.

For each landscape unit, the curve from the predictor variable with the best fit was chosen to represent the relationship between the density of the food type and soil water. 


\section{Soil water thresholds}

260 The sigmoidal relationship between the density of forage patches and soil water can be divided

261 into lag, exponential and plateau phases. The soil water thresholds marking the start and end

262 points of these phases can be represented by the points of maximum curvature on the sigmoidal

263 curves (Fig 1). The first threshold $\left(\mathrm{M}_{1}\right)$ represents the point at which availability begins to

264 increase rapidly (green-up) and the second $\left(\mathrm{M}_{2}\right)$ the point when availability nears its maximum

265 (plateau). Mixed grass had two additional thresholds, $\mathrm{M}_{3}$ and $\mathrm{M}_{4}$, for the declining phase of its

266 relationship with soil water when mixed grass is converted into green grass. For each landscape

267 unit, these thresholds were determined for the food types by calculating the local maxima of 268 curvature.

\section{Influence of soil texture, plant life-form and fire on food availability}

271 Moderated multiple regression (Aguinis 2004) was used to determine whether the linear

272 relationship between soil water threshold and soil clay content was dependent on the value of a

273 dichotomous moderator variable, which was either dummy coded plant life-form (e.g., green

274 grass $=1$, green forbs $=0$ ) or dummy coded fire (burnt $=1$, unburnt $=0)$. Separate analyses were

275 conducted for green-up and plateau thresholds and for each paired combination of plant life-

276 form. We used the standard method of determining whether a moderating effect existed, which

277 entailed the addition of a linear interaction term in the multiple regression model,

$$
Y=b_{0}+b_{1} X+b_{2} Z+b_{3} X Z
$$

where $Y$ is the soil water threshold (mm), $X$ is soil clay content (\%) and $Z$ is the dichotomous moderator variable (either plant life-form or fire). A significant interaction term $\left(b_{3}\right)$ indicates 
281 that the association between $X$ and $Y$ varied as a function of $Z$, but does not specify the form of

282 the interaction. Consequently, a significant $(\mathrm{P}<0.05)$ interaction was probed further by using the

283 Johnson-Neyman technique (Kowalski et al. 1994) to calculate the regions along the textural

284 gradient where the moderating factor had a significant effect. The regions of significance (RoS)

285 were calculated using the online application: Probing Interactions in Moderated Multiple

286 Regression and Differential Susceptibility Research

287 (http://www.yourpersonality.net/interaction/) that was designed by R. C. Fraley as a supplement 288 to Roisman et al. (2012).

289 Tests of the assumptions of moderated regression were conducted following Lund \&

290 Lund (2013). Outliers (deleted studentized residuals $> \pm 2.0$ ) were removed only if there was an

291 obvious ecological reason (e.g., soil water estimates were inaccurate because of a steep slope or

292 proximity to a perennial river), and if removal had a significant effect on the regression results.

294 Effect of soil texture and structure of woody vegetation on retention of green leaf patches

295 The maximum density of woody green leaf patches (when all woody plant canopies have $>25 \%$

296 green leaf) for each landscape unit was determined. The predictable seasonal decline in patch

297 density due to leaf drop as the dry season progresses and increase with leaf flush following

298 commencement of rains allowed per cent patch retention to be calculated for each unburnt

299 landscape unit by dividing the sum of daily patch density estimates by the maximum possible

300 patch density over the annual cycle. The relationship between per cent patch retention, soil

301 texture and woody canopy volume was then explored using the multiple non-linear regression

302 routine of Labfit (Silva \& Silva 2011). Labfit searches a library of 280 functions and outputs the 
303 one that best fits the data. Six landscape units were removed from the analysis because they were

304 affected by water-related environmental anomalies.

305

306 RESULTS

307 Temporal pattern of soil water

308 Soil water increased sharply when it rained and declined more slowly as soil dried (Fig 2). As

309 expected, soil water was highest in the wet season and clay soils stored more water per unit depth

310 than sandy ones. Time series constructed using short time lags had large, frequent fluctuations,

311 while longer lags resulted in smoother profiles.

313 Relationship between density of food patches and soil water

314 Density of herbaceous forage patches was successfully modelled from soil water using the

315 sigmoidal functions (Fig 3). Average $\mathrm{R}_{\text {adj }}$ values $( \pm \mathrm{SD}$ ) were $0.92 \pm 0.14,0.90 \pm 0.11$, and 0.89

$316 \pm 0.11$ for green grass, mixed grass and green forbs respectively. Density of woody plants with

317 green leaves was successfully modelled (average $\mathrm{R}^{2}{ }_{\text {adj }}=0.90 \pm 0.08$ ) during leaf drop and flush

318 (Fig 3) but not during the period prior to leaf drop because at this time woody plants had more

319 green leaf than predicted by soil water (Fig 4).

320

Plant life-forms responded to changes in soil water over different time scales. Grass

321 responded to short-term fluctuations, with a best predictor average ( $\pm 95 \%$ confidence interval)

322 of $29.7 \pm 5.5$ and $29.9 \pm 5.6$ days for green and mixed grass respectively. Forbs responded to

323 medium-term fluctuations, with a best predictor average of $40.6 \pm 5.9$ days, and leaves from

324 woody plants to long-term fluctuations, with an average of $99.2 \pm 8.0$ days. 


\section{Influence of soil texture and food type on soil water thresholds}

327 For all food types, the volume of soil water required to start green-up and reach maximum patch 328 density increased linearly with clay content $(\mathrm{P}<0.01)$ (Fig 5). Thresholds for woody green

329 leaves and mixed grass were well below the field capacity of the soil, the gap between field 330 capacity and threshold increasing with clay content. In contrast, plateau thresholds for green 331 grass were almost at field capacity and were above field capacity for green forbs on clay-rich

332 substrates, indicating that the assumed plateau density of 1 patch $\mathrm{m}^{-2}$ was too high for green 333 forbs.

334 Woody plants required significantly $(\mathrm{P}<0.05)$ less soil water to start greening up and 335 reach maximum patch density than green grass and forbs (Tables 1 and 2, Figs 6 and 7). Green 336 grass and forbs had the same green-up thresholds $(\mathrm{P}>0.05)$, but plateau thresholds were higher

337 for forbs on soils with greater than $14.2 \%$ clay. Thresholds for mixed grass were generally

338 similar to woody plants, but differences occurred on some soil types.

340 Temporal pattern of food availability

341 Availability of green and mixed grass was characterised by large, short-term fluctuations (Fig 8).

342 In contrast, green forbs and woody green leaves had smooth temporal profiles, giving the

343 impression that availability was unrelated to soil water. Mixed grass had lower green-up and

344 plateau thresholds than green grass and was therefore more consistently available over the annual

345 cycle. Green grass only became plentiful for a short period during the late rainy season when its

346 thresholds were exceeded. 
348 leaves and bark. The plateau threshold was not reached for forbs. Food was less available on

349 clay-rich substrates than on sandy ones, but considering the higher growth thresholds on clay

350 soils, the difference was lower than expected.

352 Effect of fire on food availability

353 The relationship between soil water and density of woody green leaf patches was not affected by

354 fire, but green-up and plateau thresholds of green grass and green forbs, and the $\mathrm{M}_{3}$ and $\mathrm{M}_{4}$

355 thresholds of mixed grass were affected (Table 2). Fire lowered $(\mathrm{P}<0.05)$ the thresholds for

356 these food types on clay-rich soils but not on sandy ones (Fig 9). This meant that on clay-rich

357 substrates, density of green grass or green forb patches was higher on burnt than unburnt areas

358 for a given volume of soil water, and that mixed grass was converted to green grass at lower

359 levels of soil water on burnt compared to unburnt sites (Fig 10).

361 Effect of soil texture and woody vegetation structure on retention of green leaf patches

362 The effect of soil clay content and woody canopy volume on retention of green leaf patches was

363 best represented $\left(\mathrm{P}<0.005, \mathrm{R}^{2}\right.$ adj $\left.=0.379\right)$ by the power function

$$
Y=a *\left(\frac{X_{1}}{X_{2}}\right) b
$$

365 where $Y$ is per cent patch retention, $X_{1}$ is per cent clay content of the top $30 \mathrm{~cm}$ of soil, $X_{2}$ is

366 woody canopy volume $\left(\mathrm{m}^{3} \mathrm{ha}^{-1}\right)$ and $a$ and $b$ are constants. Estimates of $a$ and $b$ were 106.9 and 
3670.059 respectively. Patch retention increased as clay content increased and woody canopy

368 volume decreased (Fig 11).

369

370 DISCUSSION

371 Determinants of seasonal changes in food availability

372 Savannas have been intensively studied (Sankaran et al. 2005), but drivers of forage production

373 in these environments are still only superficially understood. In this study, food availability for

374 elephants changed seasonally primarily because grasses, forbs and woody plants required

375 different volumes of soil water for development and maintenance of green foliage, and they

376 responded to fluctuations in soil moisture over different time scales. Soil texture, the structure of

377 woody vegetation and fire added further complexity by altering the soil water thresholds required

378 by the plant groups for production of green forage. Differences were apparent among growth

379 forms despite each plant group being comprised of a large number of species (woody plants =

38089 , grasses $=66$, forbs $=72$ )

381 Woody plants required less water per unit volume of soil than grasses and forbs to

382 produce green foliage. This is possibly because they have more laterally extensive root systems

383 that harvest water over a wider area, some species are deeply-rooted allowing access to deep-

384 stored water, or because they have access to an additional source of water stored in their wood

385 that can be drawn upon when soil is dry (Borchert 1994; Chapotin et al. 2006; Kulmatiski et al. 386 2010).

Grasses responded to short-term fluctuations in soil water, while woody plants and forbs responded to longer seasonal changes. Grasses appear to be geared for exploiting moisture pulses 
389 even if they are short-lived ( $<1$ month) and unseasonal, while woody plants and forbs are more

390 conservative, only responding to the more predictable, longer-term ( $1-3$ month) seasonal

391 moisture cycles (Archibald \& Scholes 2007). This difference may be explained by the ability of

392 woody plants to store water internally.

393 Soil texture in combination with plant life-form added further complexity to the

394 relationship between food availability and soil water. For all food types, green-up and plateau

395 soil water thresholds increased linearly with increasing clay content. This was expected because

396 although clay soils store more water per unit volume than sandy soils, water is more difficult to

397 extract from clay soils (Foth 1990). Despite this, woody plants retained leaf for longer on clay-

398 rich than on sandy soils. This suggests that the effect of soil texture on food availability is

399 determined by the difference between field capacity and soil water threshold rather than the

400 magnitude of the soil water threshold alone. Density of forage patches will remain at maximum

401 until soil water drops below the plateau threshold, and how long this takes to happen is

402 determined by the volume of water that the soil can store over and above the plateau threshold

403 (field capacity - plateau soil water threshold). For woody green leaves and mixed grass this

404 volume is relatively large on sandy soils and becomes even larger with increasing clay content

405 (Fig 7). For green grass and green forbs, however, the volume stored in excess of the plateau

406 threshold is relatively small on sandy soils and becomes even smaller with increasing clay

407 content. The net result is that leaves on woody plants and mixed grass stay green for longer on

408 clay-rich substrates compared to sandy ones, with the reverse being true for green grass and

409 green forbs. However, this will only happen if rainfall is sufficient to fill the clay soils to

410 capacity, as was the case in this study. 
On sandy soils forbs required the same volume of soil water as grass to reach maximum

412 patch density, but required more water than grass on clay-rich substrates. A possible explanation

413 is that greater water use efficiency of $\mathrm{C}_{4}$ photosynthesis affords grasses an advantage over $\mathrm{C}_{3}$

414 forbs on clay-rich substrates, where soil water is more difficult to extract, but not on sandy soils

415 where water is held less tightly (Ehleringer \& Monson 1993).

417 availability of green browse. Shrubs and trees retained green leaves for longer when the canopy

418 volume of woody plants was low, which was generally the case on clay-rich substrates, and shed

419 leaves earlier when canopy volume was high, which was often the case on sandy soils. In

420 accordance, mopane trees carried leaves for longer into the dry season following tree thinning

421 (Smit 2001), ostensibly as a result of reduced inter-tree competition when trees are widely

422 spaced (Smith \& Goodman 1986; Walker \& Smith 1983). The net result of woody vegetation

423 structure was a high maximum density of browse patches on sandy and loam soils that declined

424 to low density early in the dry season; and a low maximum density of browse patches on clay-

425 rich substrates that persisted for long into the dry season. Clay-rich substrates may therefore

426 support a higher density of browse patches than sandy soils during the mid-dry season, despite a

427 lower density of woody plants.

428 Fire influenced the temporal availability of food for elephants, but only for herbaceous

429 vegetation growing on clay-rich substrates. The study was conducted during the second growing

430 season after fire when the immediate effects of fire, such as barren, blackened soil surfaces, had

431 already been ameliorated by regrowth of herbaceous vegetation during the 2001/2002 growing

432 season. For a given volume of soil water, density of mixed grass, green grass, and green forb

433 patches was higher at burnt than unburnt sites. At Malilangwe, clay soils support greater grass 
434 biomass than sandy ones (Clegg 1999) and therefore greater competition among grass plants for

435 soil water is expected on clay-rich substrates. In savannas, biomass of grass may be reduced for

436 several years post-fire (Frost \& Robertson 1985; Savadogo et al. 2009; Snyman 2005), with the

437 extent of reduction determined by fire temperature (Frost \& Robertson 1985). At Malilangwe,

438 hotter fires because of larger fuel loads, and therefore greater post-fire reductions in grass

439 biomass are expected on clay compared to sandy substrates. This may result in the available soil

440 water being spread over less herbaceous biomass post-fire on clay-rich soils, and hence the lower

441 green-up and plateau soil water thresholds at burnt sites. In addition, because senescent material

442 carried over from previous seasons is removed by fire, grass has a higher ratio of live-to-dead

443 material at burnt compared to unburnt sites (Shombe et al. 2008; Van de Vijver et al. 1999),

444 which further explains the higher density of green herbaceous patches in post-fire regrowth.

445 Plants defoliated by fire may also have higher root-to-shoot ratios (Snyman 2005), and a larger

446 number of secondary and fine tertiary roots (Hartnett et al. 2005) than unburnt plants which

447 could enable them to rehydrate and green-up using less water (Fisher 1978).

448 Although fire reduced the canopy volume of the shrub layer, it had little effect on total

449 woody canopy volume because the tree layer was mostly out of reach of the flames.

450 Consequently fire did not reduce inter-tree competition for soil water, which may explain why

451 there was no post-burn effect on the temporal availability of green browse.

Although findings concerning the relationship between soil water, soil texture, fire,

453 structure of the woody layer and leaf phenology have been presented in the context of food for

454 elephants, they also have obvious significance for savannas in general. Specifically, the results

455 support the hypothesis that soil water plays a central role in the tree-grass interaction (Walter

456 1939; Walter 1970) and that explanation of this role is a key challenge towards understanding the 
457 functioning of savannas. Furthermore, we believe the insight gained into the phenological pattern

458 of forbs suggests that the hitherto reported tree-grass interaction of savannas should be expanded

459 to a tree-grass-forb interaction. However, the study was not perfectly designed to address these

460 issues so we have purposely chosen not to elaborate further on these points.

462 Implications for foraging elephants

463 In savannas elephants are confronted with a broad spectrum of food choices that change across

464 space and time. Change over the annual cycle is predictable because there is a progressive drying

465 of soil from the onset of the dry season, with food types being lost from the choice set in a

466 sequence determined by their relative soil water requirements. Food types with the highest

467 requirement are lost first, followed by the next highest and so on until only the most drought

468 resistant types remain. This corresponds with reported seasonal changes in the diet of elephants

469 from consumption of forbs and grass (high water requirement) in the rainy season to mostly

470 leaves from woody plants (medium water requirement) when rains end, followed by an

471 increasing amount of bark and roots (low water requirement) in the late dry season (Barnes 1982;

472 Cerling et al. 2004; Field 1971; Guy 1976). This understanding enables prediction of diet under

473 different scenarios. For example, in semi-arid savannas grass is expected to be utilised for longer

474 in wet than in dry years, and consumption of bark is expected to increase during drought.

475 Knowledge of the mechanisms that cause spatial variation in food availability can help to 476 explain seasonal movements of elephants. For example, because trees and grasses have different

477 soil water requirements, key browse and grass resources are often separated geographically and

478 elephants must undertake seasonal movements between them if they are to exploit their different 
479 phenological patterns. This may partly explain why elephants are often reported to move

480 between a wet season range, where grass makes up the bulk of the diet, and a dry season range

481 where browse from woody plants is the dominant food type (Cerling et al. 2006; Field 1971;

482 Loarie et al. 2009). To locate and utilise patches of green grass elephants inhabiting savanna

483 environments must track rain storms that are typically isolated and scattered (Eisinger \&

484 Wiegand 2008), which forces them to move fast (Birkett et al. 2012) and widely during the rainy 485 season (Bohrer et al. 2014; Thouless 1995; Young et al. 2009). In contrast, browse from woody 486 plants is a less ephemeral source of food and therefore elephants can move more slowly (Birkett 487 et al. 2012) and occupy a relatively confined area during the dry season (Bohrer et al. 2014; 488 Thouless 1995; Young et al. 2009).

A key challenge to the study of feeding behaviour of a wide-ranging herbivore in a complex environment is to quantify available food at an adequate spatial and temporal resolution. The approach described in this study may meet this need. The daily food supply for elephants at Malilangwe was successfully mapped for one annual cycle using this method (Clegg 2010), and the results successfully used to interpret foraging decisions that yielded generalised insight into elephant feeding behaviour that has Africa wide relevance (for monthly maps showing the spatial availability of the different forage types over the study area see Clegg 2010 pgs $60,61,66,72-74)$. Although time consuming, a ground-based approach was identified as a key to this success because estimates of patch density and the vertical distribution of browse on a species-specific basis could be derived for each food type, which is currently not possible with existing satellite technology. These measures were essential for estimating the mass and energy content of trunkloads harvested from food patches (Clegg 2010). 
502 inhabit savanna environments. However, when extrapolating the results it should be recognised

503 that elephant-centric nuances were embedded in the approach and methodology of this study. For

504 example, availability of browse patches was calculated using a maximum reach height of 4 and 6

$505 \mathrm{~m}$ for cows and bulls respectively, and browse patches were only considered available if they had

$506>25 \%$ green leaf. These nuances make the results specific to elephants. However, despite this,

507 the discerning reader should still be able to recognise the implications for other herbivores.

\section{CONCLUSIONS}

510 The types of food available to elephants changed seasonally because (1) plant life-forms required

511 different volumes of soil water to produce green forage; (2) woody plants and forbs responded to

512 long-term changes in soil moisture, while grasses responded to short-term moisture pulses; and

513 (3) soil texture, the structure of woody vegetation and fire added further complexity to the

514 pattern of food availability by altering the soil water thresholds required by the plant groups for

515 the production of green foliage.

516 Interpolating between regularly-timed, ground-based measurements of food density by

517 using modelled soil water as the predictor in regression equations proved to be a feasible method

518 of for quantifying the food available to elephants over an annual cycle. In complex

519 environments, stratification on the basis of soil texture, woody vegetation structure and recent 520 fire history is essential. 
523 The authors thank Julius Matsuve, Julius Shimbani, Cryson Chinondo and Philmon Chivambu

524 for assisting with data collection in the field. Special thanks are given to Keith Clegg for his help 525 with constructing the figures.

\section{REFERENCES}

528 Aguinis H. 2004. Regression analysis for categorical moderators. New York: Guilford Press.

529 Archibald S, and Scholes RJ. 2007. Leaf green-up in a semi-arid African savanna - separating $530 \quad$ tree and grass responses to environmental cues. Journal of Vegetation Science 18:583531594.

532 Barnes RFW. 1982. Elephant feeding behaviour in Ruaha National Park, Tanzania. African Journal of Ecology 20:123-136.

534 Bennie ATP, Coetzee MJ, Van Antwerpen R, van Rensburg LD, Burger R, and Du Toit T. 1988. A Water Balance Model for Irrigation Based on the Soil Water Supply Rate and Crop Water Requirements. Pretoria, South Africa.

537 Birkett PJ, Vanak AT, Muggeo VMR, Ferreira SM, and Slotow R. 2012. Animal perception of seasonal thresholds: changes in elephant movement in relation to rainfall patterns. PLoS ONE 7:1-8. movement closely tracks precipitation-driven vegetation dynamics in a Kenyan forestsavanna landscape. Movement Ecology 2:1-12.

543 Borchert R. 1994. Soil and stem water storage determine phenology and distribution of tropical dry forest trees. Ecology 75:1437-1449. 
545 Borchert R, Rivera G, and Hagnauer W. 2002. Modification of vegetative phenology in a tropical

546 semi-deciduous forest by abnormal drought and rain. Biotropica 34:27-39.

547 Buxton DR, and Redfearn DD. 1997. Plant Limitations to Fiber Digestion and Utilization.

$548 \quad$ Journal of Nutrition 127:8145-8185.

549 Cerling TE, Passey BH, Ayliffe LK, Cook CS, Ehleringer JR, Harris JM, Dhida MB, and Kasiki

550 SM. 2004. Orphans' tales: seasonal dietary changes in elephants from Tsavo National

551 Park, Kenya. Palaeogeography, Palaeoclimatology, Palaeoecology 206:367-376.

552 Cerling TE, Wittemyer G, Rasmussen HB, Vollrath F, Cerling CE, Robinson TJ, and Douglas-

553 Hamilton I. 2006. Stable isotopes in elephant hair document migration patterns and diet

554 changes. Proceedings of the National Academy of Sciences 103:371-373.

555 Chapotin SM, Razanameharizaka JH, and Holbrook NM. 2006. Baobab trees (Adansonia) in

556 Madagascar use stored water to flush new leaves but not to support stomatal opening

557 before the rainy season. New Phytologist 169:549-559.

558 Choler P, Sea W, Briggs P, Raupach M, and Leuning R. 2010. A simple ecohydrological model

559 captures essentials of seasonal leaf dynamics in semi-arid tropical grasslands.

$560 \quad$ Biogeosciences 7:907-920.

561 Clegg BW. 1999. Plant ecology and degradation of basalt-derived dambos in semi-arid

$562 \quad$ southeastern ZimbabweM.Sc. Thesis. University of Natal.

563 Clegg BW. 2010. Habitat and diet selection by the African elephant at the landscape level: a

564 functional integration of multi-scale foraging processes. Ph.D. Thesis. University of the

$565 \quad$ Witwatersrand.

566 Clegg BW, and O'Connor TG. 2012. The vegetation of Malilangwe Wildlife Reserve, south-

567 eastern Zimbabwe. African Journal of Range \& Forage Science 29:109-131. 
568 Clegg BW, and O’Connor TG. 2016. Harvesting and chewing as constraints to forage

569 consumption by the African savanna elephant (Loxodonta africana). PeerJ 4:e2469.

570 Cumming DHM, Fenton MB, Rautenbach IL, Taylor RD, Cumming GS, Cumming MS, Dunlop

571

572

573

574

575

576

577

578

579

580

581

582

583

584

585

586

587

588

JM, Ford AG, Hovorka MD, Johnston DS, Kalcounis M, Mahlangu Z, and Portfors CVR. 1997. Elephants, woodlands and biodiversity in southern Africa. South African Journal of Science 93:231-236.

de Boer W, Ntumi CP, Correia AU, and Mafuca JM. 2000. Diet and distribution of elephant in the Maputo Elephant Reserve, Mozambique. African Journal of Ecology 38:188-201.

de Longh HH, Tchamba MT, Aarhaug P, and Verhage B. 2004. Impact of dam construction on two elephant populations in northern Cameroon. Pachyderm 36:30-43.

Eastman JR. 2003. Idrisi Kilimanjaro Software. Clark Labs. Clark University, Worcester, M.A., USA.

Ehleringer JR, and Monson RK. 1993. Evolutionary and ecological aspects of photosynthetic pathway variation. Annual Review of Ecology and Systematics 24:411-439.

Eisinger D, and Wiegand K. 2008. SERGE: a spatially explicit generator of local rainfall in southern Africa. South African Journal of Science 104:37-42.

Field CR. 1971. Elephant ecology in the Queen Elizabeth National Park, Uganda. East African Wildlife Journal 9:99-123.

Fisher MJ. 1978. The recovery of leaf water potential following burning of two droughted tropical pasture species. Australian Journal of Experimental Agriculture and Animal Husbandry 18:423-425. 
589 Fortin AC, Merkle JA, Sigaud M, Cherry SG, Plante S, Drolet A, and Labrecque M. 2015.

590 Temporal dynamics in the foraging decisions of large herbivores. Animal Production

$591 \quad$ Science 55:376-383.

592 Foth H. 1990. Fundamentals of soil science. New York: John Wiley \& Sons, Inc.

593 Frost PGH, and Robertson F. 1985. The ecological effects of fire in savannas. In: Walker BH, ed. 594 Determinants of Tropical Savannas. Australia: IRL Press, 93-140.

595 Guy PR. 1976. The feeding behaviour of elephant (Loxodonta africana) in the Sengwa area, 596 Rhodesia. South African Journal of Wildlife Research 6:55-63.

597 Hartnett DC, Potgieter AF, and Wilson GWT. 2005. Fire effects on mycorrhizal symbiosis and 598 root system architecture in southern African savanna grasses. African Journal of Ecology $42: 337$.

Herremans M. 1995. Effects of woodland modification by African elephant Loxodonta africana 601 on bird diversity in northern Botswana. Ecography 18:440-454.

602

603

604

605

606

607

608

609

610

Hobbs TJ, Sparrow AD, and Landsberg JJ. 1994. A model of soil moisture balance and herbage growth in the arid rangelands of central Australia. Journal of Arid Environments 28:281298.

Huntley BJ. 1982. Southern African savannas. In: Huntley BJ, and Walker BH, eds. Ecology of Tropical Savannas. Berlin: Springer, 101-119.

Hutson JL. 1984. Estimation of hydrological properties of South African soilsPh.D. Thesis. University of Natal.

Kabigumila J. 1993. Feeding habits of elephants in Ngorongoro Crater, Tanzania. African Journal of Ecology 31:156-164. 
611 Kerley GIH, and Landman M. 2006. The impacts of elephants on biodiversity in the Eastern

612 Cape Subtropical Thickets. South African Journal of Science 102:395-402.

613 Kowalski CJ, Schneiderman ED, and Willis SM. 1994. ANCOVA for nonparallel slopes: the 614 Johnson-Neyman technique. International Journal of Bio-Medical Computing 37:273615286.

616 Kulmatiski A, Beard KH, Verweij RJT, and February EC. 2010. A depth-controlled tracer 617 technique measures vertical, horizontal and temporal patterns of water use by trees and 618 grasses in a subtropical savanna. New Phytologist 188:199-209.

619 KyensLab. 2002. Kyplot. 4.0. KyensLab. Japan.

620 Lamprey HF, Glover PE, Turner MIM, and Bell RHV. 1967. Invasion of the Serengeti National 621 Park by elephants. East African Wildlife Journal 5:150-167.

622 Laws RM. 1970a. Elephants and habitats in north Bunyoro, Uganda. East African Wildlife 623 Journal 8:163-180.

624 Laws RM. 1970b. Elephants as agents of habitat and landscape change in east Africa. Oikos $625 \quad 21: 1-15$

626 Leuthold W. 1977. Changes in tree populations of Tsavo East National Park, Kenya. East 627 African Wildlife Journal 15:61-69.

628 Loarie SR, van Aarde RJ, and Pimm SL. 2009. Elephant seasonal vegetation preferences across 629 dry and wet savannas. Biological Conservation 142:3099-3107.

630 Lombard AT, Johnson CF, Cowling RM, and Pressey RL. 2001. Protecting plants from 631 elephants: botanical reserve scenarios within the Addo Elephant National Park, South 632 Africa. Biological Conservation 102:191-203. 
633 Lund A, and Lund M. 2013. Moderator (dichotomous) analysis in SPSS Statistics. Available at 634 https://statistics.laerd.com/spss-tutorials/dichotomous-moderator-analysis-using-spss$635 \quad$ statistics.php (accessed 2/28/2015 2015).

636 Lyons RK, Machen R, and Forbes TDA. 1996. Why range forage quality changes? Texas Agricultural Extension Service Texas A \& M University College Station B - 6036:1-7.

638 Mapaura A, and Timberlake J. 2004. A checklist of Zimbabwean vascular plants. In: Mapaura A, 639 and Timberlake J, editors. Pretoria and Harare: Southern African Botanical Diversity

640 Network.

641

642

643

644

645

646

647

648

649

650

651

652

653

654

655

O'Connor TG, Goodman PS, and Clegg BW. 2007. A functional hypothesis of the threat of local extirpation of woody plant species by elephant in Africa. Biological Conservation 136:329-345.

O'Connor TG, and Page BR. 2014. Simplification of the composition, diversity and structure of woody vegetation in a semi-arid African savanna reserve following the re-introduction of elephants. Biological Conservation 180:122-133.

Owen-Smith RN. 1988. Megaherbivores: the influence of very large body size on ecology. Cambridge: Cambridge University Press.

Ritchie JT. 1981. Soil water availability. Plant and Soil 58:327-338.

Roisman GI, Newman DA, Fraley RC, Haltigan JD, Groh AM, and Haydon KC. 2012. Distinguishing differential susceptibility from diathesis-stress: Recommendations for evaluating interaction effects. Development and Psycopathology 24:389-409.

Sankaran M, Hanan NP, Scholes RJ, Ratnam J, Augustine DJ, Cade BS, Gignoux J, Higgins SI, Le Roux X, Ludwig F, Ardo J, Banyikwa F, Bronn A, Bucini G, Caylor KK, Coughenour MB, Diouf A, Ekaya W, Feral CJ, February EC, Frost PG, Hiernaux P, Hrabar H, 
656

657

658

659

660

661

662

663

664

665

666

667

668

669

670

671

672

673

674

675

676

677

678

Metzger KL, Prins HHT, Ringrose S, Sea W, Tews J, Worden J, and Zambatis N. 2005.

Determinants of woody cover in African savannas. Nature 438:846-849.

Savadogo P, Tigabu M, Sawadogo L, and Odén PC. 2009. Herbaceous phytomass and nutrient concentrations of four grass species in Sudanian savanna woodland subjected to recurrent early fire. African Journal of Ecology 47:699-710.

Senft RL, Coughenour MB, Bailey DW, Rittenbhouse LR, Sala OE, and Swift DM. 1987. Large herbivore foraging and ecological hierarchies. BioScience 37:789-799.

Shombe NH, Rusch GM, Hytteborn H, Skarpe C, and Kikula I. 2008. Effects of fire on sward structure and grazing in western Serengeti, Tanzania. African Journal of Ecology 46:174185.

Silva WP, and Silva CMDPS. 2011. LAB Fit Curve Fitting Software (Nonlinear Regression and Treatment of Data Program). V 7.2.48. www.labfit.net.

Smit GN. 2001. The influence of tree thinning on the vegetative growth and browse production of Colophospermum mopane. South African Journal of Wildlife Research 31:99-114.

Smith TM, and Goodman PS. 1986. The effect of competition on the structure and dynamics of Acacia savannas in southern Africa. Journal of Ecology 74:1031-1044.

Snyman HA. 2005. Influence of fire on root distribution, seasonal root production and root/shoot ratios in grass species in a semi-arid grassland of South Africa. South African Journal of Botany 71:133-144.

Spinage CA. 1994. Elephants. London: Poyser, T. \& Poyser.

SPSS. 1998. Systat. 9. SPSS Publications. Chicago.

Styles CV, and Skinner JD. 1997. Seasonal variation in the quality of mopane leaves as a source of browse for mammalian herbivores. African Journal of Ecology 35:254-265. 
679 Thouless CR. 1995. Long distance movements of elephants in northern Kenya. African Journal 680 of Ecology 33:334.

681 Van de Vijver CADM, Poot P, and Prins HHT. 1999. Causes of increased nutrient concentrations 682 in post-fire regrowth in an East African savanna. Plant and Soil 214:173-185.

683 Walker BH, and Smith TM. 1983. The role of competition in the spacing of savanna trees.

$684 \quad$ Proceedings of the Annual Congress of the Grassland Society of Southern Africa 18:159685164.

686 Walter H. 1939. Grassland, savanne und busch der aridien teile Afrikas in ihrer okologischen 687 Bedingheit. Jaarboek Wissenschaftelike Botaniek 87:10.

688 Walter H. 1970. Vegetatioszonen und klima. Jena, Germany: Gustav Fischer.

689 Wyatt JR, and Eltringham SK. 1974. The daily activity of the elephant in the Rwenzori National 690 Park, Uganda. East African Wildlife Journal 12:273-289.

691 Young KD, Ferreira SM, and van Aarde RJ. 2009. Elephant spatial use in wet and dry savannas 692 of southern Africa. Journal of Zoology 278:189-205. 


\section{Figure 1 (on next page)}

Sigmoidal curves representing the relationship between availability and soil water for the forage types.

$M_{1}=$ threshold between lag and exponential phases (green-up), $M_{2}=$ threshold between exponential and plateau phases (plateau), $M_{3}=$ threshold between plateau and exponential phases of the decline in mixed grass patches and $\mathrm{M}_{4}=$ threshold between exponential and lag phases of the decline in mixed grass patches. 


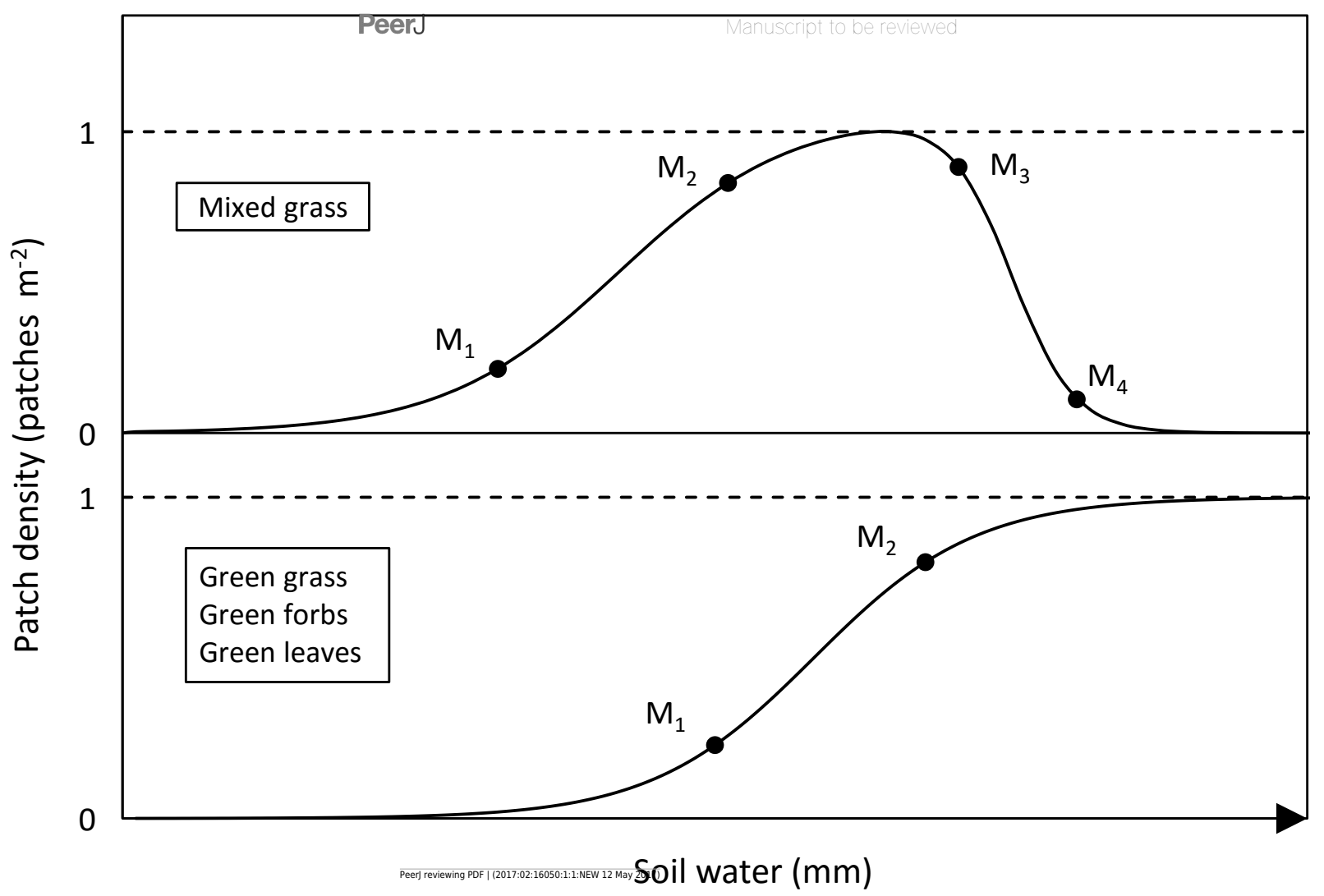


Figure 2 (on next page)

Effect of soil clay content and lag period on the temporal pattern of soil water. 


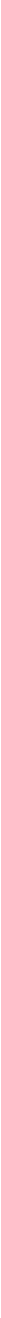




\section{Figure 3 (on next page)}

Examples of the relationship between availability of food types and soil water in relation to increasing clay content.

Mixed grass (A); green grass (B); green forbs (C); green leaves (D). Data for green leaves from woody plants are restricted to the period from the start of leaf drop, through leaf flush, to maximum patch density. 


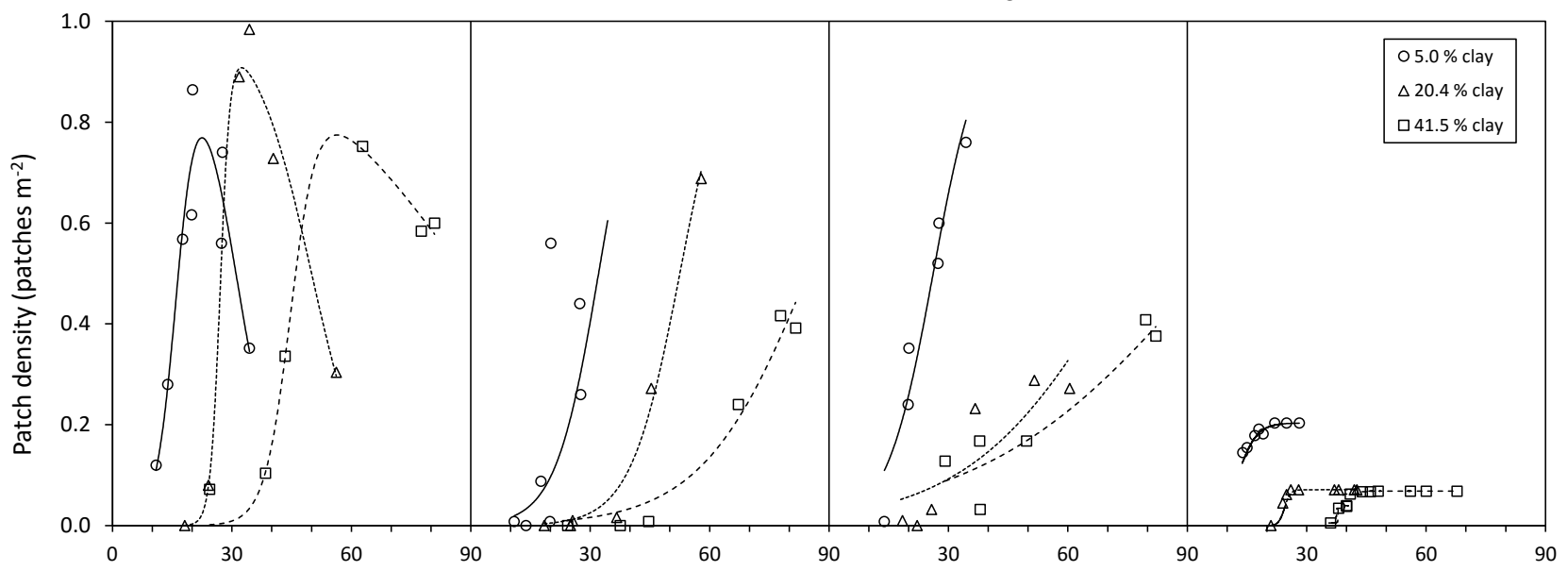


Figure 4(on next page)

Examples of temporal estimates of availability of woody green leaf available to adult bull elephants from field measurements and modelling along a gradient of increasing soil clay content.

Measured and modelled estimates corresponded well except for the period before leaf drop. 


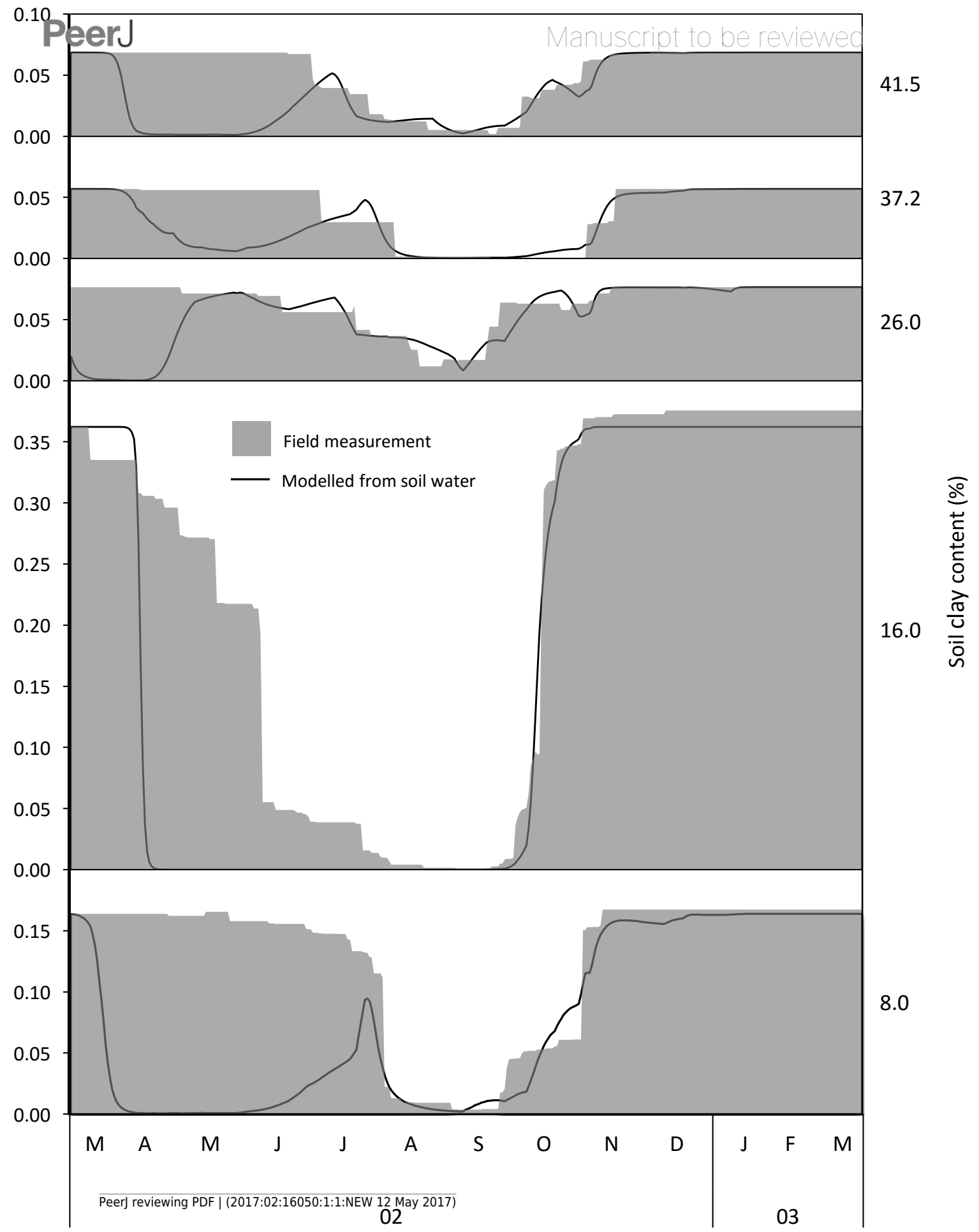




\section{Figure $\mathbf{5}$ (on next page)}

Linear regressions between clay content and field capacity of the $30 \mathrm{~cm}$ soil profile and green-up (M1) and plateau (M2) soil water thresholds for each food type.

Green leaves (A); mixed grass (B); green grass (C); green forbs (D). Equations, adjusted $\mathrm{R}^{2}$ and $P$ values for regressions: green leaves, $M_{1}=11.022+0.563 X\left(R^{2}=0.81, P<0.001\right), M_{2}$ $=12.645+0.663 X\left(R^{2}=0.87, P<0.001\right) ;$ mixed grass, $M_{1}=8.346+0.724 X\left(R^{2}=0.64, P<\right.$ $0.001), M_{2}=13.423+0.774 X\left(R^{2}=0.54, P<0.001\right) ;$ green grass, $M_{1}=18.671+1.225 X\left(R^{2}\right.$ $=0.69, P<0.001), M_{2}=26.22+1.673\left(R^{2}=0.70, P<0.001\right) ;$ green forbs, $M_{1}=10.52+$ $1.502 X\left(R^{2}=0.68, P<0.001\right), M_{2}=18.493+2.63 X\left(R^{2}=0.68, P<0.001\right)$. 
A PeerJ

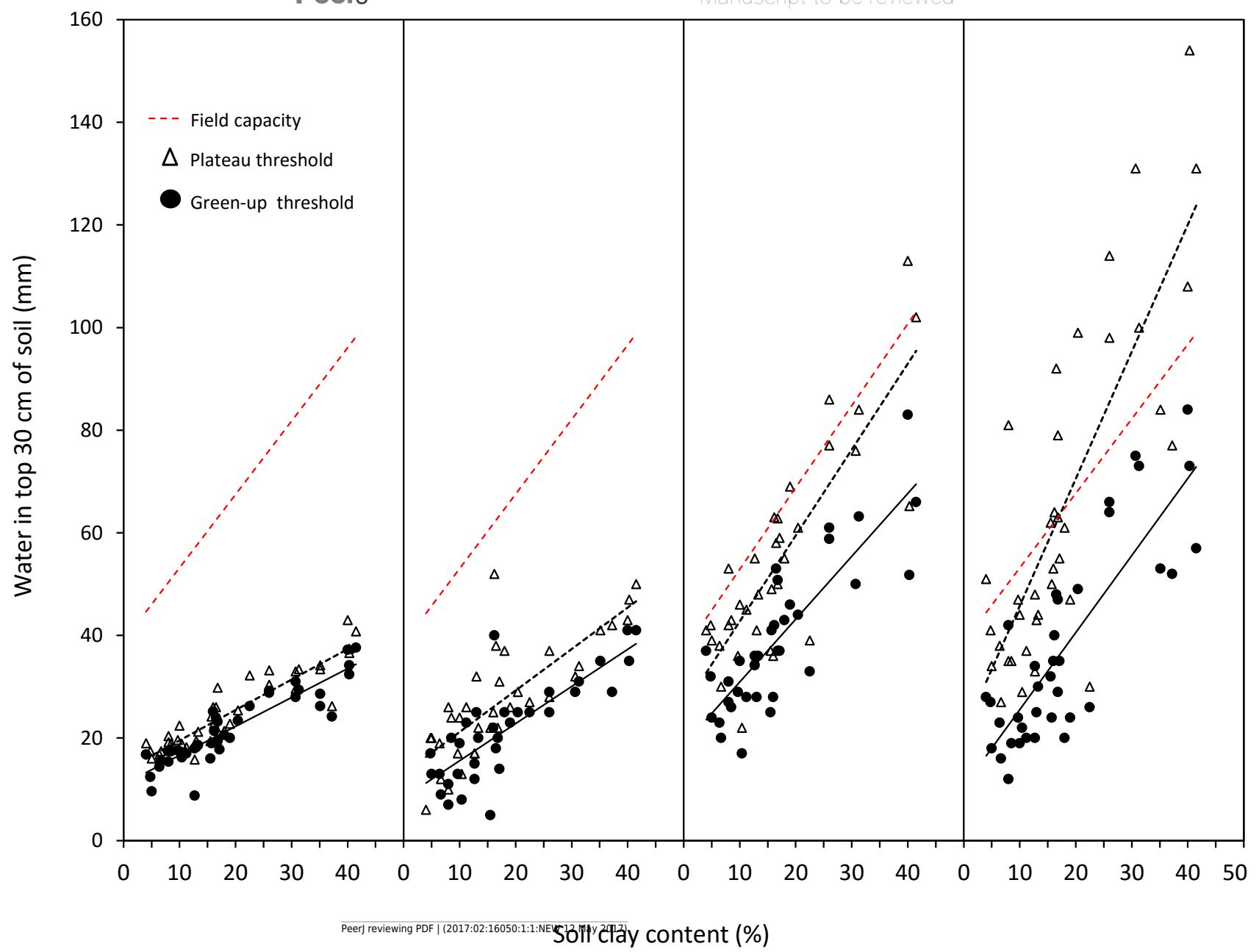




\section{Figure 6 (on next page)}

Effect of soil clay content and food type on green-up (M1) soil water thresholds.

Regions of significant $(P<0.05)$ differences between green leaves and mixed grass $(A)$, green leaves and green grass (B), green leaves and green forbs (C), mixed grass and green grass (D), mixed grass and green forbs (E), and green grass and green forbs (F) are shaded grey. 


\section{Figure 7 (on next page)}

Effect of soil clay content and food type on plateau (M2) soil water thresholds.

Regions of significant $(P<0.05)$ differences between green leaves and mixed grass $(A)$, green leaves and green grass (B), green leaves and green forbs (C), mixed grass and green grass (D), mixed grass and green forbs (E), and green grass and green forbs (F) are shaded grey. 
A PeerJ

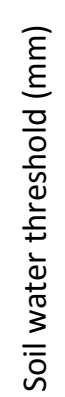

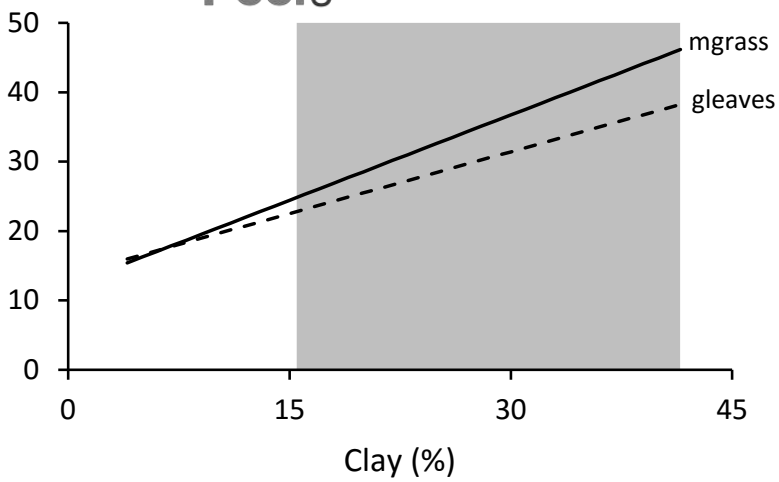

C

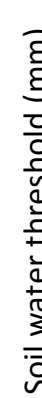

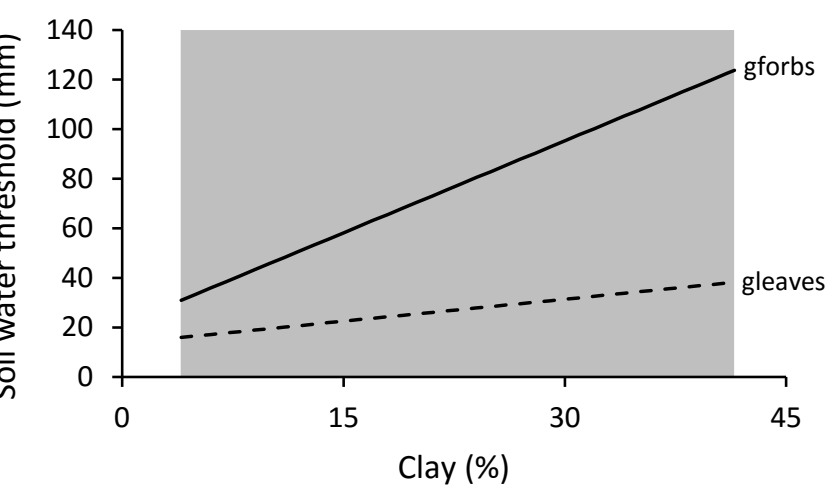

E

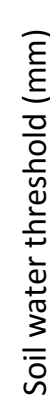

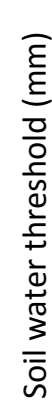

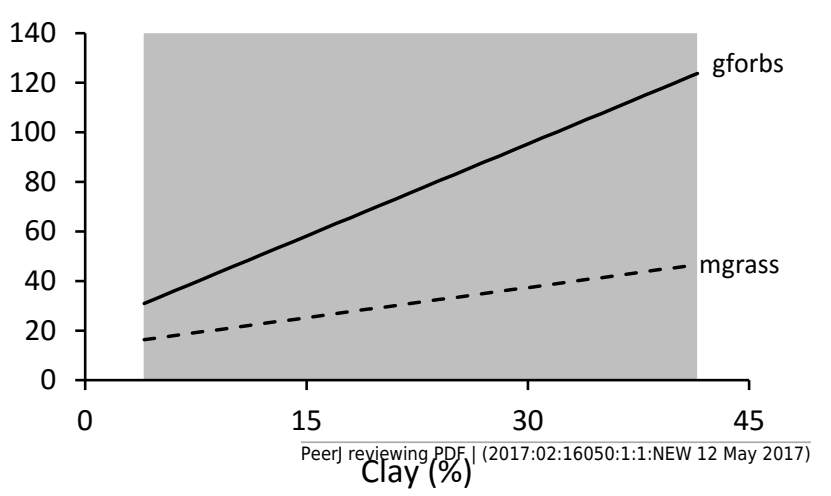

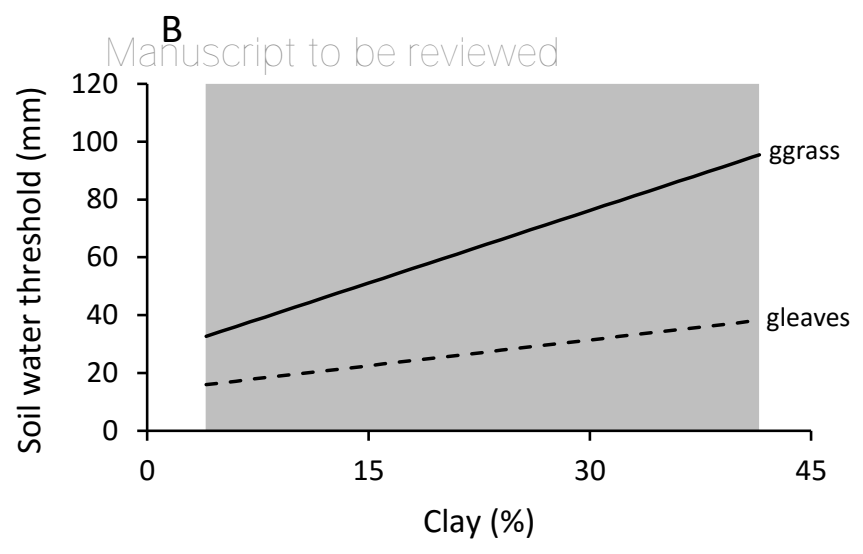
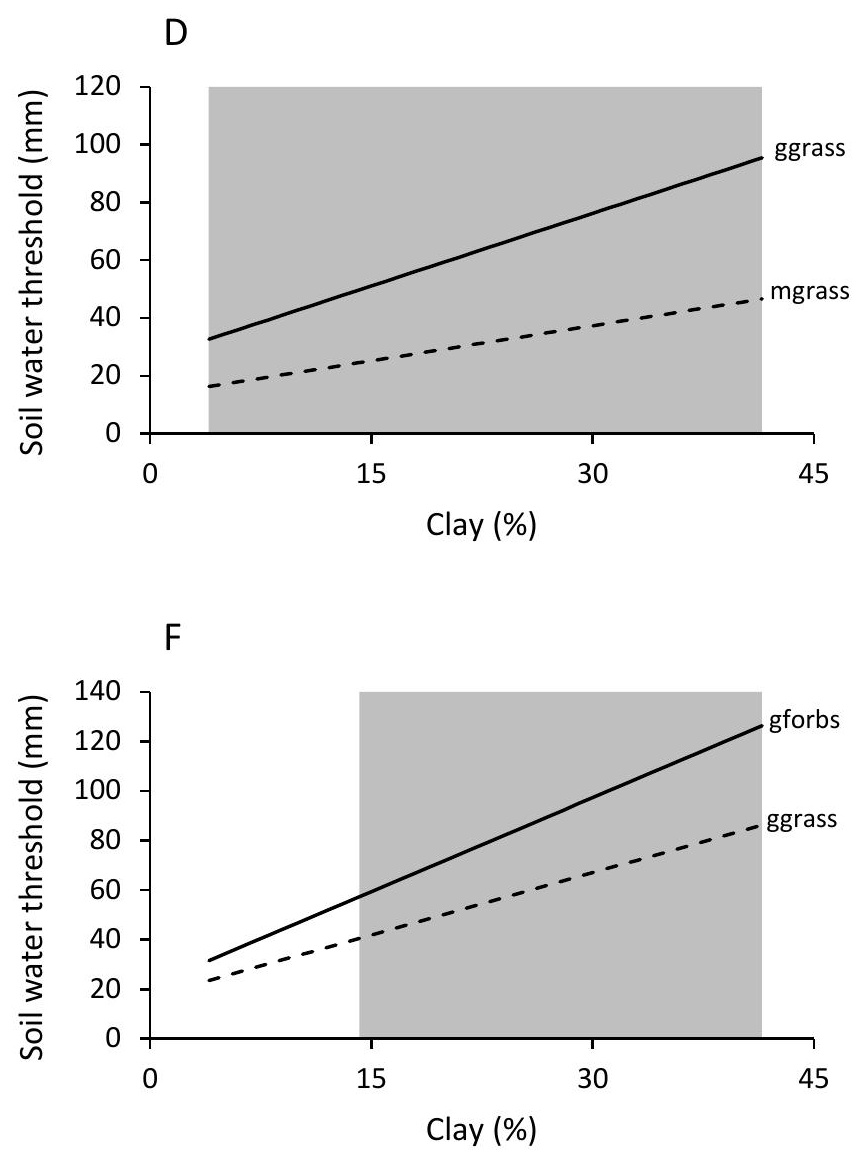


\section{Figure 8 (on next page)}

Temporal availability of forage types along a gradient of increasing clay content.

Data for woody green leaves are for adult bulls. Availability of woody green leaf was slightly lower for cows, but otherwise followed the same pattern. 
PeerJ

Soil clay content (\%)

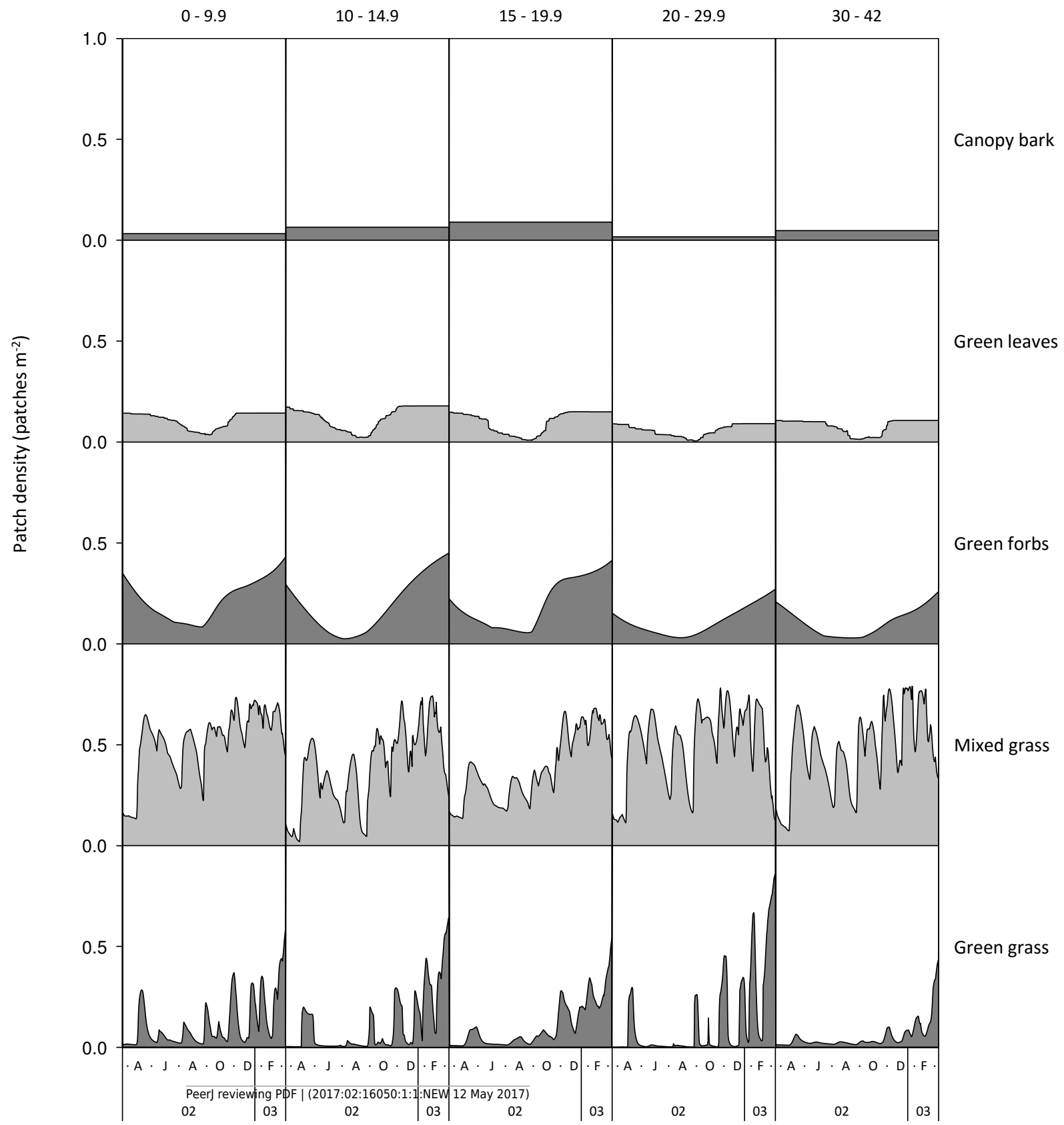




\section{Figure 9 (on next page)}

Effect of a significant interaction between soil clay content and fire ( $>5$ months previously) on soil water thresholds for green grass, green forbs and mixed grass.

Green grass $M_{1}(A)$; green grass $M_{2}(B)$; green forbs $M_{1}(C)$; green forbs $M_{2}(D)$; mixed grass $M_{3}$ $(E)$; mixed grass $M_{4}(F)$. Regions of significant $(P<0.05)$ difference between burnt and unburnt areas are shaded grey. 
Figure 10 (on next page)

Examples of the effect of fire ( $>5$ months previously) on the patch density - soil water relationship for herbaceous forage types along a gradient of increasing clay content. 
PeerJ Clay in top $30 \mathrm{~cm}$ of soil (\%) $\mathrm{cript}$ to be reviewed

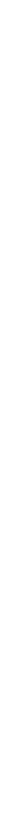


Figure 11

Influence of soil clay content and woody canopy volume on retention of green leaf patches.

$Y=a *(X 1 / X 2) b$, where $Y=$ patch retention, $X 1=$ soil clay content, $X 2=$ woody canopy volume, and $\mathrm{a}$ and $\mathrm{b}$ are constants.

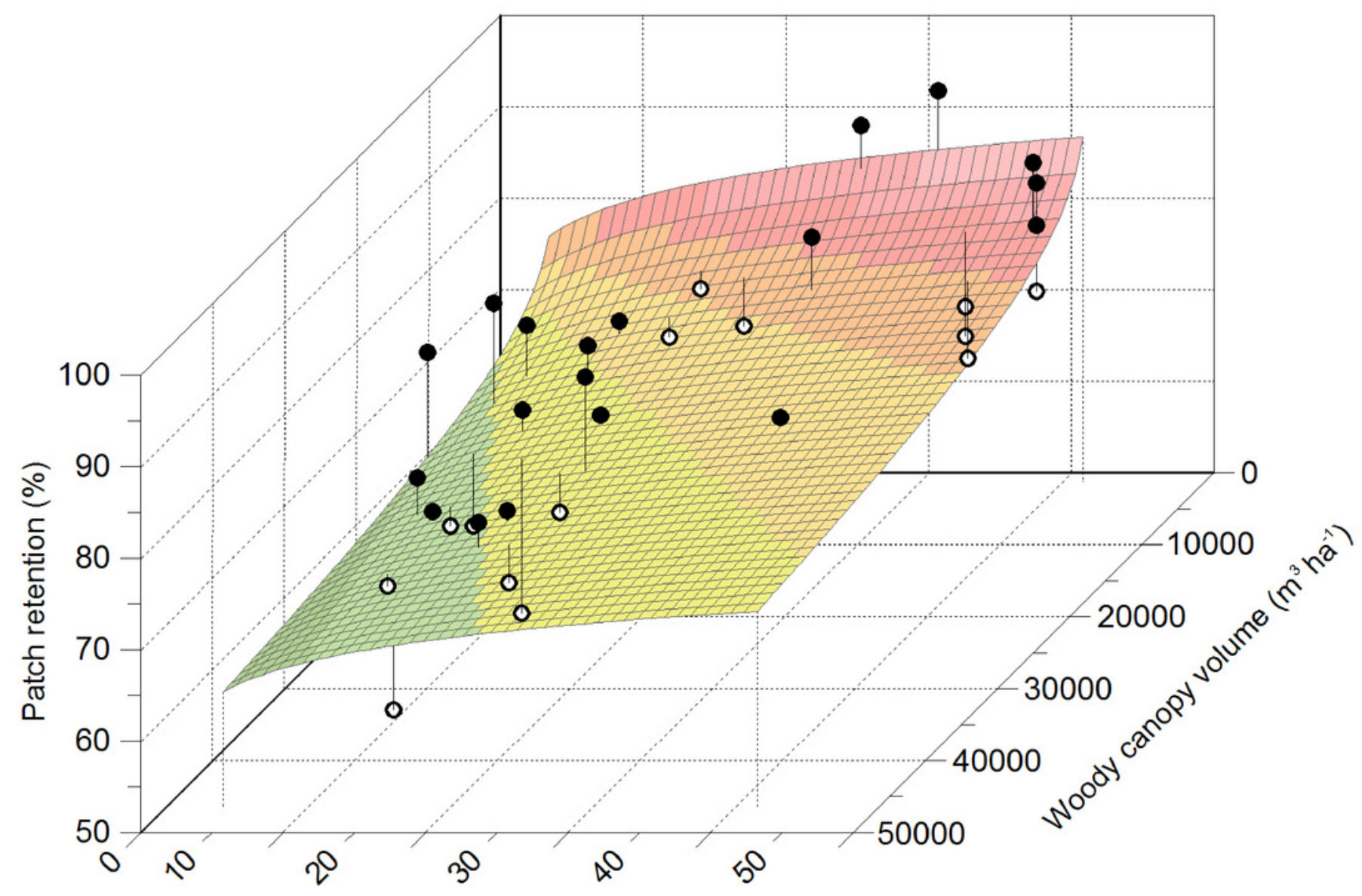

Clay content of top $30 \mathrm{~cm}$ of soil (\%) 


\section{Table $\mathbf{1}$ (on next page)}

Regression estimates and region of significance limits ( $\operatorname{RoS} X)$ for the influence of soil texture and plant life-form on soil water thresholds. 


\begin{tabular}{|c|c|c|c|c|c|c|c|c|c|c|}
\hline \multirow[b]{2}{*}{$\begin{array}{l}\text { Threshold } \\
\text { (Y) }\end{array}$} & \multicolumn{2}{|c|}{$\begin{array}{c}\text { Dummy coded } \\
\text { Moderator variable } \\
(Z)\end{array}$} & \multicolumn{6}{|c|}{ Regression estimates } & \multicolumn{2}{|c|}{ RoS X (Clay \%) } \\
\hline & 1 & 0 & $b_{0}$ & $b_{1}$ & $b_{2}$ & $b_{3}$ & $X Z \Delta \mathrm{R}^{2}$ & $p$ & $\begin{array}{l}\text { Lower } \\
\text { bound }\end{array}$ & $\begin{array}{l}\text { Upper } \\
\text { bound }\end{array}$ \\
\hline $\mathrm{M}_{1}$ & G. leaves & M. grass & $8.164^{* *}$ & $0.724^{* *}$ & $3.342^{*}$ & $-0.174^{*}$ & 0.015 & 0.019 & 32.8 & 41.5 \\
\hline $\mathrm{M}_{1}$ & G. leaves & G. grass & $18.671^{* *}$ & $1.225^{* *}$ & $-7.650 * *$ & $-0.662 * *$ & 0.06 & 0.0005 & 4.0 & 41.5 \\
\hline $\mathrm{M}_{1}$ & G. leaves & G. forbs & $14.543^{* *}$ & $1.458^{* *}$ & $-5.682^{*}$ & $-0.783 * *$ & 0.087 & 0.0005 & 4.0 & 41.5 \\
\hline $\mathrm{M}_{1}$ & M. grass & G. grass & $18.671^{* *}$ & $1.225^{* *}$ & -10.325 & $-0.501 * *$ & 0.027 & 0.0005 & 4.0 & 41.5 \\
\hline $\mathrm{M}_{1}$ & M. grass & G. forbs & $10.518^{* *}$ & $1.502 * *$ & -2.172 & $-0.779 * *$ & 0.058 & 0.0005 & 5.6 & 41.5 \\
\hline $\mathrm{M}_{1}$ & G. grass & G. forbs & $10.518^{* *}$ & $1.502^{* *}$ & 8.153 & -0.278 & 0.007 & 0.22 & - & - \\
\hline $\mathrm{M}_{2}$ & G. leaves & M. grass & $12.129 * *$ & 0.82 & 1.469 & $-0.226^{*}$ & 0.02 & 0.016 & 15.5 & 41.5 \\
\hline $\mathrm{M}_{2}$ & G. leaves & G. grass & $25.984 * *$ & $1.674^{* *}$ & $-12.386 * *$ & $-1.080 * *$ & 0.075 & 0.0005 & 4.0 & 41.5 \\
\hline $\mathrm{M}_{2}$ & G. leaves & G. forbs & $21.025^{* *}$ & $2.475^{* *}$ & -7.427 & $-1.882^{* *}$ & 0.111 & 0.0005 & 4.0 & 41.5 \\
\hline $\mathrm{M}_{2}$ & M. grass & G. grass & $25.984 * *$ & $1.674^{* *}$ & $-12.883^{* *}$ & $-0.866 * *$ & \begin{tabular}{|l|}
0.046 \\
\end{tabular} & 0.0005 & 4.0 & 41.5 \\
\hline$M_{2}$ & M. grass & G. forbs & $21.025^{* *}$ & $2.475^{* *}$ & -7.924 & $-1.667^{* *}$ & 0.084 & 0.0005 & 4.0 & 41.5 \\
\hline $\mathrm{M}_{2}$ & G. grass & G. forbs & $21.374 * *$ & $2.529 * *$ & 4.610 & $-0.855^{*}$ & \begin{tabular}{|l|}
0.025 \\
\end{tabular} & 0.018 & 14.2 & 41.5 \\
\hline
\end{tabular}

${ }^{*} \mathrm{P}<0.05,{ }^{* *} \mathrm{P}<0.01$

2

3

4

5 


\section{Table 2 (on next page)}

Regression estimates and region of significance limits ( $\operatorname{RoS} X)$ for the influence of soil texture and fire ( $>5$ months previously) on soil water thresholds. 


\begin{tabular}{|c|c|c|c|c|c|c|c|c|c|c|}
\hline \multirow[b]{2}{*}{ Threshold $(Y)$} & \multicolumn{2}{|c|}{$\begin{array}{l}\text { Dummy coded } \\
\text { moderator } \\
\text { variable }(Z)\end{array}$} & \multicolumn{6}{|c|}{ Regression estimates } & \multicolumn{2}{|c|}{$\operatorname{RoS} X$ (Clay \%) } \\
\hline & 1 & 0 & $b_{0}$ & $b_{1}$ & $b_{2}$ & $b_{3}$ & $X Z \Delta \mathrm{R}^{2}$ & $p$ & Lower & $\begin{array}{l}\text { Upper } \\
\text { bound }\end{array}$ \\
\hline G. leaves $\mathrm{M}_{1}$ & Burnt & Unburnt & $11.134^{* *}$ & $0.581^{* *}$ & 0.498 & -0.077 & 0.003 & 0.202 & - & - \\
\hline M. grass $M_{1}$ & Burnt & Unburnt & $8.346^{* *}$ & $0.724 * *$ & $6.861^{*}$ & -0.301 & 0.026 & 0.1 & - & - \\
\hline G. grass $M_{1}$ & Burnt & Unburnt & $15.298 * *$ & $1.461 * *$ & 7.626 & $-0.536 *$ & 0.029 & 0.022 & 23.6 & 41.5 \\
\hline G. forbs $M_{1}$ & Burnt & Unburnt & $10.518^{* *}$ & $1.502^{* *}$ & 12.336 & $-0.862 *$ & 0.052 & 0.012 & 23.4 & 41.5 \\
\hline G. leaves $\mathrm{M}_{2}$ & Burnt & Unburnt & $13.144^{* *}$ & $0.631 * *$ & -0.776 & -0.059 & 0.002 & 0.403 & - & - \\
\hline $\mathrm{M}$. grass $\mathrm{M}_{2}$ & Burnt & Unburnt & $12.129 * *$ & $0.820 * *$ & 5.742 & -0.277 & 0.018 & 0.130 & - & - \\
\hline G. grass $M_{2}$ & Burnt & unburnt & $22.807^{* *}$ & $1.973^{* *}$ & -0.463 & $-0.629 *$ & 0.021 & 0.040 & 12.5 & 41.5 \\
\hline G. forbs $M_{2}$ & Burnt & unburnt & $21.025^{* *}$ & $2.475^{* *}$ & 11.389 & $-1.381 *$ & 0.046 & 0.025 & 18.5 & 41.5 \\
\hline$M$. grass $M_{3}$ & Burnt & Unburnt & $19.349 * *$ & $1.285^{* *}$ & 7.228 & $-0.627 *$ & 0.041 & 0.016 & 20.7 & 41.5 \\
\hline$M$. grass $M_{4}$ & Burnt & Unburnt & $23.848^{* *}$ & $1.983 * *$ & 7.985 & $-1.087 * *$ & 0.053 & 0.006 & 15.9 & 41.5 \\
\hline
\end{tabular}

